\title{
Культурологія
}

УДк 008:379.8

\author{
Петрова Ірина Владиславівна \\ доктор культурології, профресор, \\ профресор кафедри івент-менеджменту та \\ індустрії дозвілля Київського національного \\ університету культури і мистецтв \\ ORCID 0000-0002-8146-9200 \\ petrovaiw@gmail.com
}

\section{СВЯТКОВА КУЛЬТУРА ВЕРСАЛЮ ЯК ЗАСІБ РЕПРЕЗЕНТАТИВНОÏ ПОЛІТИКИ ЛЮДОВІКА XIV}

\begin{abstract}
Мета дослідження полягає в обґрунтуванні специфіки та фрункції святкових практик Версалю як засобу репрезентативної політики Людовіка XIV. Методологія дослідження ґрунтується на міждисциплінарному підході, який увібрав у себе системний, аналітичний, історичний, компаративний, культурологічний методи, що дозволило обґрунтувати особливості святкової культури в конкретній історичній обумовленості й охарактеризувати версальські святкування у контексті реалізації ними функції репрезентативності. Наукова новизна полягає у дослідницькому ракурсі означеної проблематики: святкова культура Версалю, її еволюція, вивчається у контексті синтезу бажань конкретної особи (Людовіка XIV) та формування державної політики. Обґрунтовується думка про важливість святкової культури у формуванні іміджу держави та підтримки національної єдності. Висновки. Інкорпоровані у придворну дійсність, святкові дійства виконували численні завдання, серед яких: конкретизація наявної при дворі ієрархії, демонстрація престижності соціального статусу придворної особи; репрезентація королівської влади з метою зміцнення та утримання соціальних зв'язків з одного боку та «одомашнення», применшення значимості дворянства - 3 іншого; насичення святкової культури відповідними політичними змістами та символічними значеннями. Святкові практики Версалю мали специфічні ознаки, зокрема, характеризувалися безпосередньою участю у них «Короля-Сонця», символічністю, відповідним змістово-функціональним насиченням події, змаганнєвістю, синтезом мистецтв. Сукупність означених вище завдань та характерних рис дозволяють стверджувати, що Версальські свята були символом державної та політичної могутності.
\end{abstract}

Ключові слова: святкова культура, видовищна придворна культура, Версаль, Король-Сонце, культурні практики, свято.

Петрова Ирина Владиславовна, доктор культурологии, профрессор, профрессор кафредры ивентменеджмента и индустрии досуга Киевского национального университета культуры и искусств

Праздничная культура Версаля как способ репрезентативной политики Людовика XIV

Цель исследования состоит в обосновании специфики и функции праздничных практик Версаля как средства репрезентативной политики Людовика XIV. Методология исследования основана на междисциплинарном подходе, который охватывает системный, аналитический, исторический, компаративный, культурологический методы, что позволило обосновать особенности праздничной культуры в конкретной исторической обусловленности и охарактеризовать версальские празднования в контексте реализации ими функции репрезентативности. Научная новизна заключается в исследовательском ракурсе обозначенной проблематики: праздничная культура Версаля, ее эволюция, изучается в контексте взглядов конкретного лица (Людовика XIV) и формирования им государственной политики. Обосновывается мнение о важности праздничной культуры в укреплении имиджа государства и поддержки национального единства. Выводы. Инкорпорированная в придворную действительность, праздничная культура выполняла многочисленные задания, среди которых: конкретизация имеющейся при дворе иерархии, демонстрация престижности социального статуса придворного; репрезентация королевской власти с целью укрепления и удержания социальных связей с одной стороны и «одомашнивания», умаления значимости дворянства - с другой; насыщение праздничной культуры соответствующими политическими смыслами и символическими значениями. Праздничные практики Версаля имели специффические признаки, в частности, характеризовались непосредственным участием в них «Короля-Солнца», символизмом, соответствующим содержательно-функциональным насыщением события, синтезом искусств, соревновательностью. Совокупность указанных выше задач и отличительных черт позволяют утверждать, что Версальские праздника были символом государственной и политической мощи.

Ключевые слова: праздничная культура, зрелищная придворная культура, Версаль, Король-Солнце, культурные практики, праздник.

Petrova Iryna, D.Sc. in Cultural studies, Professor of Event Management and Leisure Industry Department, Kyiv National University of Culture and Arts

Versailles festive culture as a way of representational police of Louis XIV

The purpose of the article deals with the justification of the specificity and functions of Versailles festive practices as the way of a representational policy of Louis XIV. The methodology of the research is based on the interdisci-

() Петрова І. В., 2019 
plinary approach which combined systemic, analytical, historical, comparative methods and method of culture study that allowed justify the features of festive culture in specific historical conditions and characterize Versailles feasts in context of realization representative function by them. Scientific novelty deals with the research aspect of the problem: Versailles festive culture, their evolution is studied in the context of synthesis of desires of the person ( Louis XIV) and the formation of state policy. The think of the importance of festive culture in creation of state image and support of national unity is justified in the research. Conclusion. Festive actions, which were incorporated in court reality, solved many problems, such as specification of court hierarchy, demonstration of prestige of social status of court individuality; representation of Royal poverty for the porpoise of strengthening and maintenance of social relations from one side and "domestication," derogation of nobility meaning - from other; satiation of festive culture by appropriate political contexts and symbolic values. Festive practices of Versailles had the specific features; in particular, they were characterized by direct participation of "King-Sun," symbolist, appropriate context and functional satiation of action, adventure, synthesis of arts. A set of the problems mentioned above and characteristic features allowed to say that Versailles feasts were the symbol of state and political power.

Key words: festive culture, spectacular court culture, Versailles, King-Sun, cultural practices, feast.

Актуальність дослідження. Версаль є не лише унікальною пам'яткою світової культурної спадщини, але й уособленням мистецтва святкових звеселянь та розваг, культури дозвілля, які у роки правління Короля-Сонця досягли небувалого злету й слугували прикладом для більшості тодішніх європейських королівств. Достатньо лише згадати такі святкування як «Звеселяння чарівного острова» (1664) або ж «Великий королівський дивертисмент» (1668). Щоправда, передували їм урочистості у заміській резиденції Во ле Віконт (належала суперінтенданту фінансів Ніколо Фуке), влаштовані на честь молодого короля Людовіка XIV. Розкішні бали й ілюмінації, паркові пленери й прогулянки, тріумфальні арки, алеї та боскети, театральні видовища й музичні вечори, сприймалися не як витратна зайвина, а як нагальна потреба двору, метою якої було формування у королівських підлеглих сприйняття свята як символу державної та політичної могутності.

Актуальність останніх досліджень та публікацій. Увагу вчених Версаль привертає, переважно, як парковий комплекс (М. Алпатов, В. Курбатов, Д. Ліхачов); культурно-мистецький ансамбль, що уособлює цінності абсолютизму та світоглядні орієнтації цієї епохи (Г. Алфьорова, Ю. Віппер, Н. Хеншелл, С. Шервінський, А. Якимович); своєрідний «історико-культурний проект Нового часу» (Е. Карапетян, Ж. Лєнотр, Н.Мітфорд, Ю. Сабадаш, О. Савін), із притаманною лише йому культурою повсякдення (Ф. Блюш, Ф. Боссан, Е. Дешодт, І. Мюра, М.Нєклюдова, Ж. К. Птіфіс, О. Шален).

Проте версальські свята як засіб репрезентації державної політики Короля-Сонця й до сьогодні залишаються у вітчизняній культурології майже невивченою темою, а спроби проаналізувати святкову культуру найвідомішої у світі королівської резиденції у контексті її впливу на формування державної політики, у вітчизняній науковій традиції відсутні.

Недолік достатньої кількості сучасної дослідницької літератури, у якій висвітлюється й обґрунтовується значимість придворної святкової культури як засобу формування державної політики, вдалося компенсувати завдяки використанню першоджерел. Так, придворне життя Франції епохи «Короля-Сонця» збережено на сторінках численних мемуарів та листів, щоденників, записів і літературних творів (д’Артаньян, Дюбуа, Лабрюйєр, Ларошфуко, Ментенон, Мольєр, Рец, Севіньє, Сен-Сімон, Перро, Феліб'єн),

Метою статті є спроба обґрунтувати специфіку та функції святкових практик Версалю як засобу репрезентативної політики Людовіка XIV.

Виклад основного матеріалу. Актуалізація святкової практики як соціального міфу, супроводжувана видовищною маніфестацією, укорінювала думку про те, що формувати істинних придворних та людей честі може лише «гідне» придворне дозвілля $[3,16]$. Значимість останнього - у процесі фрормування двору як впливової владної інституції, що фрокусувала увесь спектр соціальних зв'язків, виконуючи одночасно роль регулятора економічного, культурного, духовного життя суспільства, його ідеології та поведінських орієнтирів. Натомість головною та єдиною заслугою придворних вважалося «вміння коритись» $[6,204]$.

Монарху недостатньо декларувати авторитет, його потрібно реалізовувати й зберігати у боротьбі з численними (зовнішніми та внутрішніми) ворогами $[5,10]$. I саме для досягнення цієї мети використовувалися версальські свята - вони слугували значимим індикатором взаємовідносин між владою й суспільством, засобом пропагування й репрезентації влади правителя з одного боку й символом служіння з іншого. Як влучно зазначав Лабрюєр, «найдієвіша політика, до якої споконвіку вдаються у багатьох країнах - це присипляти народ святами, видовищами, розкошами, насолодами, втіхами, самовдоволенням і зманіженістю, бавити його дурницями» [6, 192].

Розуміння сутності й значимості святкової культури видається неможливим без аналізу характерних ознак такого явища як двір періоду абсолютистської монархії, у якому придворні кола об'єднувалися між собою, формуючи сталий образ життя. Н. Еліот пише, що двір відігравав роль соціального фрільтру, завдяки якому відбувався взаємозв'язок королівського оточення з країною, і навпаки, двір та придворне життя формували життєвий досвід короля, його уявлення про людей та навколишній світ. Країна розчинялася у дворі, а двір був продовженням країни; державні події поєднувалися й міцно спліталися із приватним життям короля, для якого держава як така не представляла самостійної 
цінності, оскільки істинною цінністю могло бути лише королівське життя [21, 170]. На свою країну король, який, здавалося, мав необмежену «монополію на можливості», впливав завдяки посередництву придворних. І він же був змушений утримувати під жорстким контролем розподіл серед цих осіб певних можливостей задля утримання ним влади, дистанції й королівського престижу [там само, 171].

Згідно з даними, наведеними Н. Еліотом, 1744 р. у версальському палаці постійно проживало близько десяти тисяч осіб (із прислугою включно) [21, 103]. Громадська думка, сформована у замкненому світі придворної еліти, мала вирішальне значення для існування особи при дворі, тому залежність окремої людини від визнання її елітарної ідентичності іншими членами цієї соціальної групи була неймовірно великою [там само, 120-121]. У результаті, приналежність особи до королівського двору набула неабиякої соціальної значимості [21, 201], а сам двір почав реалізувати завдання залежності придворної аристократії від королівської особи за одночасної втрати самостійної ролі дворянства [там само, 222-229]. Поступово королівський двір формується як обмежений простір державної еліти із лише йому притаманними звичаями, правилами поведінки, стилем життя, унаслідок чого зростає соціальне відокремлення й розвивається придворна культура, з притаманними лише їй рисами [21, 230]. 3а часів Людовіка XIV соціальні розбіжності між придворним та провінційним дворянством настільки потужні, що королівський двір представляє собою не просто замкнену соціальну верству, але й верству, істотно відмінну від «інших світських суспільних організацій епохи» [там само, 292]. Чи були придворні вільні у своєму життєвому виборі? Чи обмежувався їх спосіб пересування? Чи могли вони за власним бажанням й не втративши свого соціального статусу покинути двір?

На ці питання можемо отримати відповіді, проаналізувавши змістово-функціональне наповнення святкових звеселянь та урочистостей монаршого двору. Версаль, як символ абсолютної монархії та придворного життя, символізував життя «урочисте, пишне, величне, вільне, розмірене..., життя парадне, упорядковане, прикрашене високим мистецтвом, трагедіями Расіна, комедіями Мольєра, музикою Люллі, спорудами Перро, декоративним мистецтвом Ленотра» [17]. Навіть буденний день версальського двору сповнений, на перший погляд, лише розвагами й звеселяннями. Так, у одному із листів м-м де Севіньє (1676) міститься опис її типового суботнього візиту до королівського двору. Значний обсяг листа присвячено аналізові палацового життя, що зводиться до гри у карти, бесід, вечірніх прогулянок, катання на гондолах, слухання музики, перегляду комедій, нічних розваг [17]. Проте, уявна придворна «абсолютна свобода» підтримується завдяки ґрунтовно розробленій стратегії маніпулятивного управління придворними, застосування політики «приборкання», у якій значиму роль відіграють світські звеселяння, сповнені «великою політичною грою парламентських партійних битв» [21, 122]. Як зауважує Н. Хеншелл, і святкова культура, і придворний церемоніал, виконують роль декорацій задля здійснення основної мети королівської влади - управління елітою. Двір використовується королем як своєрідна арена, на якій змагаються опозиційні партії, відбувається оцінка монархом своїх придворних, усуваються потенційно небезпечні угруповання й підтримується паритет між переможцями. I при цьому - будь-яке видовище мусить демонструвати «безумовну одностайність» [20].

Зокрема, і версальське свято «Звеселяння чарівного острова» (1664), і «Великий королівський дивертисмент» (1668), й святкування, присвячені завоюванню Франш-Конте (1674) були складовими політичної програми, засобом формування «справжніх» придворних, з одного боку, а $з$ іншого - мали утверджувати велич Людовіка XIV і могутність французької державності. Дотримання у королівському палаці атмосфери галантного спілкування, ретельне виконання правил придворного етикету демонстрували державні єдність й порядок, систему, стрижень якої становило дворянство як обрана й відокремлена верства.

Згадуване вище свято «Звеселяння чарівного острова» - чи не найвідоміше святкування галантного століття - присвячувалося королеві-матері Анні Австрійській, королеві Марії Терезії та Луїзі де Лавальєр. Урочисте святкування було насичене спектаклями, іграми, лотереями, балетами, кінними змаганнями та численними феєрверками. Перший день розпочався з кінної каруселі, очолюваної королем (він - у ролі Рудж'єрі, його придворні - у костюмах різних персонажів з поеми Аріосто «Шалений Роланд»), й завершився розкішними концертом та нічним бенкетом, супроводжуваним переглядом присутніми балету. Наступні дні свята були насичені театралізованими виставами, змаганнями, лотереями, нічними променадами та іншими звеселяннями, після яких «кожен вважав своїм обов'язком сказати про свято щось улесливе» й висловити можновладцю захоплення його небувалою щедрістю, майстерністю в організації події й умінням усім догодити [3, 52]. Головною діючою особою протягом усього придворного святкування був Король, який започаткував цим дивовижним «Звеселянням...» нову епоху в святковій культурі Франції.

Наступне звеселяння - «Великий королівський дивертисмент» (1668) - відбулося у версальському парку, який, на той час зазнав кардинальних змін: було збудовано дванадцять нових боскетів (Грот Тетіс, Водяний партер та Фонтан Латоні, Фонтан Дракона, Водяний павільйон, боскет Водяної альтанки, боскет Дофіна та боскет Жирандоль), звіринець та лабіринт. Свято складалося із прогулянок у парку, коласйону, перегляду вистави Мольєра «Жорж Данден, або Обдурений чоловік» у театрі, створеному Вігарані й розрахованому на 1500 глядачів, які стали безпосередніми учасниками балетів й інтермедій, узагальнених під темою «Свята Любові й Бахуса» (на музику Люллі й слова Мольєра). Свято завершилося урочистою вечерею, балом, феєрверком та ілюмінаціями. 
Проте воно кардинально відрізнялося від «Звеселянь ...», адже «перше було романним та поетичним, друге - офіційним. Перше мало зачаровувати, друге - утверджувати велич. Перше визначалося темою, друге - змістом» $[2,66]$. Придворні святкування, влаштовані ніби-то заради розваг та любовних утіх, мали чітко визначені цілі. Версальська феєрія є прикладом ефективного поєднання розваг з політикою, адже «Великий королівський дивертисмент» присвячено мирній угоді, згідно 3 якою Валлонська Фландрія перейшла у володіння Франції.

Бали й маскаради, кінні перегони і любовні розваги, полювання й прогулянки, гра у більярд чи перегляд вистав, мали й інші завдання: відволікти придворних від політичних інтриг і конфліктів, заохотити знать до служіння, утримати дворян при дворі, а водночас: спостерігати за ними, висловлювати підданим свою повагу і влаштовувати своєрідне змагання між дворянами у вірності й покорі Королю. Як зазначає Н. Еліас, «збереження напруженої ситуації серед підданих було для короля життєво важливим, оскільки єдність між ними, безумовно, становила б загрозу його власному існуванню» [21, 161]. Л. Сен-Сімон у своїх «Мемуарах» писав, що король використовував численні свята, прогулянки й заміські поїздки як засіб винагороди або ж покарання [19]. У результаті, придворні «не лише тому прибували до двору, що залежали від короля, а й залишалися залежними від короля тільки тому, що прибувши до двору і перебуваючи серед придворних, вони могли зберігати дистанцію від усіх інших. Від дотримання цієї дистанції залежав порятунок їхньої душі, їх престиж як придворних аристократів, а отже, їх суспільне існування і їх особиста ідентичність» [21, C125]. Двір як втілення «неперервного спектаклю» (Ф. Блюш) спонукає до реалізації функції підтримки залежності придворних від монаршої особи та дотримання відповідної дистанції. Так, особливим привілеєм для придворного є отримання запрошення на театральну прем'єру [1, 154]. Цю функцію «фетишу престижу» (Н. Еліас) доволі важко реалізувати, а реалізувавши - втримати: «Хто є більшим невільником, ніж запопадливий придворний? Хіба що ще запопадливіший придворний» $[6,171]$. Внаслідок цього «захват від спектаклю, гучні оплески в театрі Мольєра та Арлекіна, обіди, полювання, бали й кінні перегони - лише прикриття для тривог, турбот і різноманітних розрахунків, побоювань і надій, бурхливих пристрастей і серйозних справ» $[6,170]$.

Не менш видовищними були й королівські розваги, присвячені завоюванню Франш-Конте (1674). Святкування тривали протягом декількох літніх місяців: гостям пропонуються прогулянки у парку, розкішні пригощання, театральні вистави, концерти й балети, плавання на гондолах, супроводжувані феєрверками й небаченим досі освітленням $[1,156]$. Лейтмотивом усього святкування $є$ військові перемоги короля. Недаремно О. Бенуа порівняє Версаль із храмом єдиної волі, сприйнятої усіма заради загальної королівської величі, храмом своєрідної гармонії, збудованим на складному і глибокому сприйнятті ієрархії.

Святкові практики Версалю мають специфічні ознаки, серед яких необхідно вказати на:

- безпосередню участь «Короля-Сонця» у палацових розвагах та залежність святкових уподобань придворних від поглядів, смаків, пристрастей і бажань можновладця;

- символічний характер святкувань. Яскравими прикладами, які мали продемонструвати присутнім велич, могутність та політичну владу короля, є урочистий в'їзд монарха у Париж у 1660 р.; або ж супровід Людовіка XIV лицарями у турнірі у 1662 р., коли перший тримав у руках дзеркало (що відбивало сонячні промені), другий - гілку лавра (священного дерева сонця), третій - орла (який злітав до сонця); чи видовища у Комп'єні, що мали на меті презентацію нескореності фрранцузьких військ після невдалої війни з Аугсбурзькою лігою. Подібних прикладів можна навести незліченну кількість;

- використання у святкових видовищах технологічних досягнень, які забезпечували видовищну маніфестацію свят (від створення ілюзії тривимірного простору у парку, світлових та сценічних ефектів, живих скульптур до залу машинерії в Тюільрі Вігарані);

- відповідне змістово-фуункціональне насичення події, яке визначало її соціальну значимість та демонструвало пріоритети монарха;

- змагальність як публічну демонстрацію придворних за першість (змагальність у всьому у вишуканості вбрання чи демонстрації вірнопідданства, в улесливості чи акторській майстерності);

- синтез мистецтв (садово-паркового, декоративно-прикладного, образотворчого, музичного, театрального, хореографрічного, творів архітектури) та стильової взаємодії (від бароко до класицизму, від карнавально-бурлескних розваг до благородного спектаклю), об'єднаних у придворних видовищах.

Після проголошення Версалю офіційною королівською резиденцією видовищні святкування трансформуються у Апартаменти короля. Організовані декілька разів на тиждень й за чітко визначеним розкладом, вони пропонуватимуть придворним численні ігри (баккара, віст, більярд, карти), концерти, танці, театральні та оперні вистави. Проте така жорстка регламентація перетворить дозвіллєві практики Версалю на буденне рутинне життя (Ф. Боссан).

Наукова новизна полягає у дослідницькому ракурсі означеної проблематики: святкова культура Версалю, її еволюція, вивчається у контексті синтезу бажань конкретної особи (Людовіка XIV) та 
формування державної політики. Обґрунтовується думка про важливість святкової культури у формуванні іміджу держави та підтримки національної єдності.

Висновки. Інкорпоровані у придворну дійсність, святкові дійства (церемонії, ритуали, манери й правила поведінки) виконували численні завдання, серед яких: конкретизувати наявну при дворі ієрархію, стверджуючи престижність соціального статусу придворної особи; демонструвати й репрезентувати королівську владу з метою зміцнення та утримання соціальних зв'язків з одного боку та «одомашнення», применшення значимості дворянства - 3 іншого; насичувати святкову культуру відповідними політичними змістами та символічними значеннями, формуючи країну й об'єднуючи націю.

Сценарій будь-якого свята передбачав дотримання принципу «логічного взаємозв'язку» та «єдиного порядку» (Сент-Еньян, розпорядник спеціальної Служби королівських задоволень). Численні дозвіллєві практики (прогулянки, турніри, змагання, концерти, пригощання тощо) та різноманітна «машинерія» (палатки, сцени, декорації, гірлянди, розписи), що використовувалася під час проведення свята, спрямовувалися на досягнення певних цілей та відповідали ідейному змісту величі, непереможності й першості монарха. Версальські святкування, спрямовувалися на репрезентацію політики Людовіка XIV, й були символом державної та політичної могутності.

\section{תimepamypa}

1. Блюш Ф. Людовик XIV. Пер. Л. Д. Тарасенковой, О. Д. Тарасенкова. Москва: Ладомир, 1998. 815 с.

2. Боссан Ф. Людовик XIV, король-артист. Москва: Аграф, 2002. 265 с.

3. Версаль / Автор-составитель Е.А. Конькова. Москва: Вече, 2008. 240с.

4. Дешодт Э. Людовик XIV; пер. с фрр. Москва: Молодая гвардия; Палимпсест, 2011. 286 с.

5. Королевский двор в политической культуре средневековой Европы. Отв. ред. Хачатурян Н.А. Москва: Наука, 2004. 540 с.

6. Лабрюєр Жан де. Характери, або звичаї нинішнього віку / пер. із фрр. Г. Малець. Київ: ПУЛЬСАРИ, 2009. -364 c.

7. Ленотр Ж. Повседневная жизнь Версаля при королях / пер. с фр. М.: Молодая гвардия, 2003. 230 с.

8. Мемуары мессира д'Артаньяна: в 3 т. Т. 2. / Пер. с фр. М. Поздняковой. М.: «АНТАНТА Лтд», 1995.

$448 \mathrm{c}$.

9. Митфорд Н. Франция. Придворная жизнь в эпоху абсолютизма. - Смоленск: Русич, 2003. 560 с.

10. Мольер Ж.-Б. Полное собрание сочинений в одном томе / Пер. с фрр. М.: Альфа-книга, 2009. Электронный ресурс http://lib.rus.ec.

11. Неклюдова М.С. Галантная картография и модели репрезентации фрранцузского двора середины XVII в. Французский ежегодник 2014: Жизнь двора во Франции от Карла Великого до Людовика XIV / Под ред. А.В. Чудинова и Ю.П. Крыловой М.: ИВИ РАН, 2014. С. 252-268.

12. Птифис Ж.-К. Людовик XIV. Слава и испытания; пер. с фр. СПб.: Евразия, 2008. 382 с.

13. Ракова А. Версальские праздники Короля-Солнце. СПб.: Изд-во Гос. Эрмитажа, 2004. 16 с.

14. Ракова А. Л. Праздник - любимая игрушка государей // Торжества и празднества в европейской гравюре XVI-XVIII столетий из собрания Эрмитажа [каталог выставки]. СПб.: Гос. Эрмитаж, 2004. 144 с.

15. Рец, кардинал де. Мемуары; пер. с фр. М.: Ладомир, 1997. 831с.

16. Сабадаш Ю. Гуманізм як феномен італійської культури К.: ДАКККіМ, 2008. 361 с.

17. Савин А. Век Людовика XIV. М.: Гос. изд-во, 1930. 248 с.

18. Севинье, мадам де. Письма; пер с фр. СПб.: Азбука; Азбука-Аттикус, 2012. 304 с.

19. Сен-Симон Л. Мемуары: полные и доподлинные воспоминания герцога де Сен-Симона о веке Людовика XIV и Регентстве. Кн. 1: Избр. главы. Пер. с фр. М. : Прогресс, 1991. 598 с.

20. Хеншелл Н. Миф абсолютизма: Перемены и преемственность в развитии западноевропейской монархии раннего Нового времени. URL: https://libking.ru/books/nonf-/nonfiction/393654-30-nikolas-henshell-mifabsolyutizma-peremeny-i-preemstvennost-v-razvitii-zapadnoevropeyskoy-monarhii-rannego-novogo-vremeni.html\#book.

21. Элиас Н. Придворное общество: Исследования по социологии короля и придворной аристократии, с Введением: Социология и история / Н. Элиас // пер. с нем. А. П. Кухтенкова, К. А. Левинсона, А. М. Перлова, Е. А. Прудниковой, А. К. Судакова. - М. : Языки славянской культуры, 2002. - 368 с.

2005. $288 \mathrm{C}$.

22. Эрланже Ф. Эпоха дворов и королей. Этикет и нравы в 1558-1715 гг.; пер. с англ. Смоленск: Русич,

23. Burke P. Louis XIV: Les stratégies de la gloire; traduit de l'anglais. Lonrai: Éditions du Seuil, 2007. 327 p.

24. Felibien A. Les Divertissemens de Versailles, donnez par le Roy au retour de la conqueste de la FrancheComte, en l'annee 1674. URL: http://gallica.bnf.fr/ark:/12148/btv1b8626218b.r=Felibien.langEN.

25. Louis XIV. Mémoires. Manière de visiter les jardins de Versailles. Paris: Tallandier, 2007. 353 p.

\section{References}

1. Blyush, F. (1998). Lyudovik XIV. (L. D. Tarasenkovoy, O. D. Tarasenkova, Trans). Moscow: Ladomir [in Russian].

2. Bossan, F. (2002). Lyudovik XIV, artist king. Moscow: Agraf [in Russian].

3. Versal. Ye.A. Konkova (Ed.). (2004). Moscow: Veche [in Russian].

4. Deshodt, E. (2011). Lyudovik XIV. Trans. from fr. Moscow: Molodaya gvardiya; Palimpsest [in Russian]. [in Russian].

5. The royal court in the political culture of medieval Europe. N.A. Khachaturyan (Ed.). Moscow: Nauka, 2004

6. Labrjujer Zhan de. (2009). The characteristics or customs of the present age. (Gh. Malecj, from. with fr.). Kyiv: PULJSARY [in Ukrainian]. 